Halaman 1-8

\title{
Penerapan Pendekatan Kontekstual melalui Model Pembelajaran \\ Investigasi Kelompok untuk Meningkatkan Keterampilan Sosial Siswa Kelas X-3 SMA Negeri 1 Boyolali Tahun Pelajaran 2012/2013
}

The Application of Contextual Approach Using Group Investigation Learning Model to Improve the Social Skills of the X-3 Graders of SMA Negeri 1 Boyolali in The School Year of 2012/2013

\author{
Chandra Adi Prabowo ${ }^{1}$, Puguh Karyanto ${ }^{1}$, \\ Baskoro Adi Prayitno ${ }^{1}$, Ristanti Yustin ${ }^{2}$ \\ ${ }^{1}$ Pendidikan Biologi FKIP Universitas Sebelas Maret, \\ Email: chandradipra@ rocketmail.com \\ ${ }^{2}$ SMA Negeri 1 Boyolali, Email: yustinbio@gmail.com
}

Diterima 2 Agustus 2013, disetujui 3 September 2013

\begin{abstract}
The purpose of the research to improve the social skill of the X-3 graders of SMA Negeri 1 Boyolali in the school year of 2012/2013 by applying the contextual approach with group investigation learning model. Research method was a Classroom Action Research designed some cycles encompassing 4 stages: planning, acting, observing, and reflecting. The subject of research was the X-3 graders of SMA Negeri 1 Boyolali in the school year of 2012/2013. The data was obtained using non-test technique including interview and questionnaire. The data was analyzed using a descriptive qualitative technique as well as data validation using technique triangulation. Result of the research showed the improved achievement of student social skills. The conclusion was that the application of contextual approach using group investigation learning model could improve the social skill of the X-3 graders of SMA Negeri 1 Boyolali in the school year of 2012/2013.
\end{abstract}

Key Words: Contextual Approach, Group Investigation, Social Skill

\section{Pendahuluan}

Permasalahan yang terjadi pada kelas X-3 SMA Negeri 1 Boyolali adalah tidak terjalinnya kerjasama serta komunikasi yang baik antar siswa di kelas sehingga terjadi sikap saling berkompetisi. Sikap saling berkompetisi tersebut menyebabkan munculnya kesenjangan hasil belajar antar siswa. Permasalahan tersebut dapat muncul karena rendahnya keterampilan sosial siswa.
Keterampilan sosial yang perlu dimiliki siswa agar proses pembelajaran dapat berjalan dengan baik menurut John Jarolimek mencakup tiga aspek yaitu: (1) Living and working together; (2) taking turns, respecting the rights of others, being socially sensitive, Learning selfcontrol and self-direction; (3) Sharing ideas and experience with others. (Ningrum, 2009)

Guru dituntut untuk mampu mengatasi permasalahan yang muncul di kelas melalui berbagai pendekatan. Salah satu cara untuk mewujudkan keberha- 
silan kegiatan pembelajaran adalah dengan memilih model, media, dan strategi pembelajaran yang sesuai sehingga siswa dapat menerima materi pelajaran dengan baik (Ulansari \& Yonata, 2012).

Pembelajaran kontekstual merupakan suatu konsep belajar yang menuntut siswa untuk aktif dan saling bekerjasama untuk berbagai pengalaman dengan siswa lain. Dengan bekerjasama siswa terbantu dalam menemukan persoalan, merancang rencana dan mencari pemecahan masalah (Johnson, 2011).

Salah satu model pembelajaran yang sesuai untuk diterapkan melalui pendekatan kontekstual adalah pembelajaran kooperatif. Pembelajaran kooperatif merupakan pembelajaran secara aktif melibatkan siswa dalam kegiatan pembelajaran sehingga mampu secara efektif meningkatkan kognitif, kemampuan afektif dan interpersonal siswa (Nagel, 2008).

Model pembelajaran Investigasi kelompok merupakan suatu model pembelajaran kooperatif yang menuntut siswa untuk terlibat aktif dalam kegiatan pembelajaran mulai dari tahap penentuan topik hingga tahap evaluasi akhir pembelajaran, selain itu juga menuntut siswa untuk memiliki keterampilan yang baik dalam berkomunikasi serta bekerjasama dengan siswa lain untuk dapat menyelesaikan tugas yang diberikan (Sharan, 2011).

Pembelajaran berbasis kelompok menawarkan metode pembelajaran yang menuntut siswa untuk lebih cermat, melakukan debat dengan siswa lain serta meningkatkan kemampuan artikulasi siswa. Pembelajaran berbasis kelompok merupakan metode terbaik untuk diterapkan untuk pembelajaran berbasis praktek yang sangat komplek (Judy Gillespie, 2012)

Berdasarkan kesesuaian strategi tersebut dengan permasalahan yang terjadi di kelas X-3, maka peneliti melakukan penelitian berjudul, "Penerapan Pendekatan Kontekstual melalui Model Pembelajaran Investigasi Kelompok untuk Meningkatkan Keterampilan Sosial Siswa Kelas X-3 SMA Negeri 1 Boyolali Tahun Pelajaran 2012 / 2013”.

\section{Metode Penelitian}

Penelitian ini merupakan penelitian tindakan kelas yang dilaksanakan dalam 2 siklus. Setiap Siklus terdiri atas 4 tahapan yaitu perencanaan, tindakan, observasi, dan refleksi. Subjek penelitian adalah kelas X-3 SMA Negeri 1 Boyolali Tahun Pelajaran 2012/2013.

Teknik yang digunakan untuk mengumpulkan data keterampilan sosial siswa adalah dengan metode non tes yang 
diwujudkan dalam instrumen berupa angket dan wawancara.

Teknik analisis data angket yaitu menggunakan teknik analisis deskriptif kualitatif sedangkan data hasil wawancara mengacu pada model analisis Miles dan Huberman yang dilakukan dalam 3 komponen yaitu reduksi data, penyajian data, dan penarikan kesimpulan atau verifikasi (Sugiyono, 2011).

Prosedur dan langkah-langkah dalam penelitian tindakan kelas ini mengikuti model yang dikembangkan Kemmis dan Mc. Taggart yang berupa model spiral yaitu dalam satu siklus terdiri dari tahap perencanaan, tindakan, observasi dan refleksi (Supardi, 2009). Target capaian hasil yang ditetapkan dalam penelitian adalah capaian rata-rata kelas adalah $75 \%$ pada setiap aspek keterampilan sosial.

\section{Hasil dan Pembahasan}

Hasil penelitian di kelas X-3 SMA Negeri 1 Boyolali Tahun Pelajaran 2012/2013 menunjukkan bahwa penerapan pendekatan kontekstual melalui model pembelajaran investigasi kelompok dapat meningkatkan keterampilan sosial siswa. Peningkatan keterampilan sosial siswa tersebut meliputi 3 aspek yaitu:

1. Kerjasama
Persentase capaian aspek kerjasama pada siklus I adalah sebesar 73,00 \% dan siklus II sebesar 79,64\%.

2. Komunikasi

Persentase capaian aspek komunikasi pada siklus I adalah sebesar $71,67 \%$ dan siklus II sebesar 78,39\%.

\section{Menghargai}

Persentase capaian aspek menghargai pada siklus I adalah sebesar $68,33 \%$ dan siklus II sebesar 75,18\%.

Hasil capaian di atas dapat disajikan dalam bentuk grafik seperti pada gambar 1 .

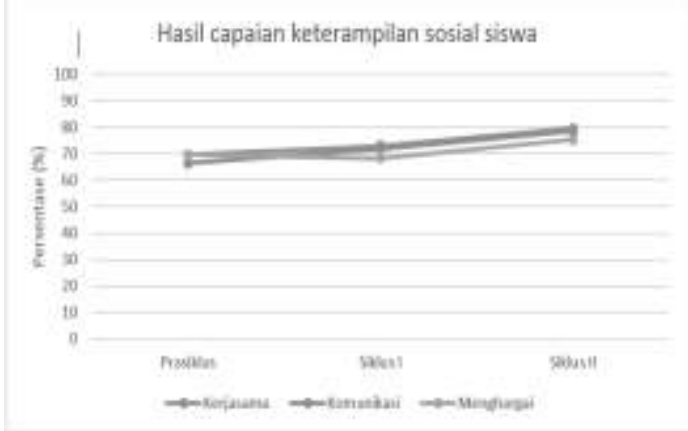

Gambar 1. Peningkatan hasil capaian keterampilan sosial

Gambar 1 di atas menunjukkan bahwa penerapan pendekatan kontekstual melalui model pembelajaran investigasi kelompok dapat meningkatkan keterampilan sosial siswa kelas X-3 SMA Negeri 1 Boyolali Tahun Pelajaran 2012/2013. Hasil tersebut dilihat dari peningkatan hasil keterampilan sosial siswa.

1. Kerjasama 
Kerjasama merupakan pekerjaan yang dilakukan oleh suatu kelompok sehingga terdapat hubungan antar tugas dan pekerjaan setiap anggota kelompok, demikian pula penyelesaiannya.

Dalam aspek kerjasama terdapat 4 indikator yang digunakan dalam angket keterampilan sosial siswa yang meliputi kontribusi terhadap kelompok, kualitas pekerjaan, bekerja bersama siswa lain dan manajemen waktu.

Pembelajaran yang menerapkan model investigasi kelompok memungkinkan guru untuk mengembangkan keterampilan kerjasama siswa karena karakteristik pembelajaran kooperatif yang lebih terfokus pada penilaian kinerja kelompok.

Persentase capaian indikator pada aspek kerjasama pada tiap siklus disajikan pada Tabel 1.

Tabel 1. Hasil Capaian Indikator Aspek Kerjasama

\begin{tabular}{|c|c|c|}
\hline \multirow{2}{*}{ Indikator } & \multicolumn{2}{|c|}{ Pencapaian (\%) } \\
\hline & Siklus I & Siklus II \\
\hline $\begin{array}{ll}\text { Kontribusi } & \text { Terhadap } \\
\text { Kelompok } & \end{array}$ & 72,50 & 83,93 \\
\hline Kualitas Pekerjaan & 86,67 & 91,07 \\
\hline $\begin{array}{l}\text { Bekerja Bersama } \\
\text { Siswa Lain }\end{array}$ & 65,42 & 76,79 \\
\hline Manajemen Waktu & 73,33 & 84,82 \\
\hline
\end{tabular}

capaian indikator pada aspek kerjasama.

Berdasarkan tabel tersebut diketahui bahwa capaian tertinggi pada siklus 2 adalah bekerja bersama siswa lain yaitu 91,07\% sedangkan kontribusi terhadap kelompok menunjukkan hasil capaian terendah yaitu $83,93 \%$.

Peningkatan hasil capaian setiap indikator pada aspek kerjasama disajikan pada gambar 2 .

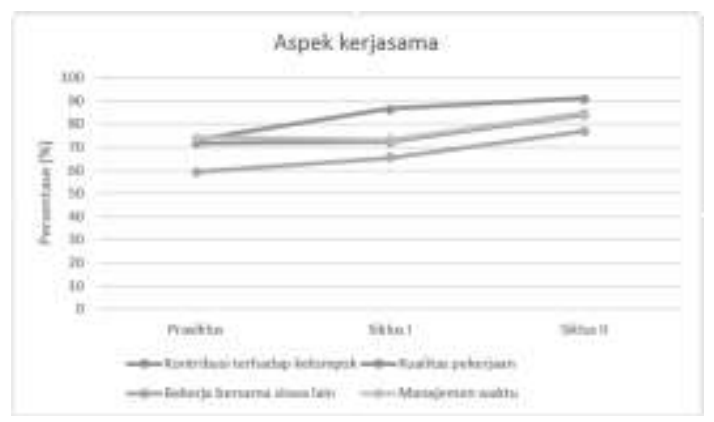

Gambar 2. Peningkatan indikator aspek kerjasama

Gambar 4.2 menunjukkan bahwa setiap indikator pada aspek kerjasama mengalami peningkatan tiap siklus. Mana-jemen waktu mengalami penurunan pada siklus 1 namun menunjukkan peningkatan pada siklus 2 .

Pembelajaran yang menerapkan model investigasi kelompok memungkinkan guru untuk mengembangkan keterampilan kerjasama siswa karena karakteristik pembelajaran kooperatif yang lebih terfokus pada penilaian kinerja kelompok.

Kegiatan pembelajaran didukung dengan penerapan pendekatan kontekstual yang semakin menguatkan pengembangan aspek kerjasama dalam pembelajaran. Salah satu komponen utama dalam pendekatan kontekstual adalah komunitas belajar yaitu siswa dituntut untuk dapat memperoleh hasil 
belajar secara optimal melalui kerjasama dan komunikasi dengan siswa lain. Kerjasama merupakan komponen penting yang dikembangkan dalam CTL karena merupakan salah satu cara siswa untuk saling berbagi pengetahuan dengan siswa lain sehingga didapatkan hasil pembelajaran yang bermakna (Johnson, 2011).

\section{Komunikasi}

Keterampilan berkomunikasi dalam pembelajaran memiliki peran yang sangat penting karena siswa perlu untuk dapat menyampaikan informasi yang dimiliki baik secara lisan maupun tertulis sehingga siswa lain dapat menerima informasi tersebut.

Dalam aspek komunikasi terdapat 4 indikator yang digunakan dalam angket keterampilan sosial siswa yang meliputi materi yang disampaikan, pengorganisasian, penggunaan bahasa dan penyampaian.

Persentase capaian indikator aspek komunikasi pada tiap siklus disajikan pada Tabel 2.

Tabel 2. Hasil Capaian Indikator Aspek Komunikasi

\begin{tabular}{lll}
\hline \multirow{2}{*}{ Indikator } & \multicolumn{2}{l}{ Pencapaian $(\%)$} \\
\cline { 2 - 3 } & Siklus I & Siklus II \\
\hline Materi yang & 75,00 & 84,82 \\
disampaikan & 78,33 & 88,39 \\
Pengorganisasian & 72,50 & 85,71 \\
Penggunaan bahasa & 75,45 \\
Penyampaian & 67,08 & \\
\hline
\end{tabular}

Tabel 2 di atas menunjukkan hasil capaian indikator pada aspek komunikasi. Berdasarkan tabel tersebut diketahui bahwa capaian tertinggi pada siklus 2 adalah pada indikator pengorganisasian yaitu $88,39 \%$ sedangkan penyampaian menunjukkan hasil capaian terendah yaitu 75,45\%.

Peningkatan hasil capaian setiap indikator pada aspek komunikasi disajikan pada Gambar 3.

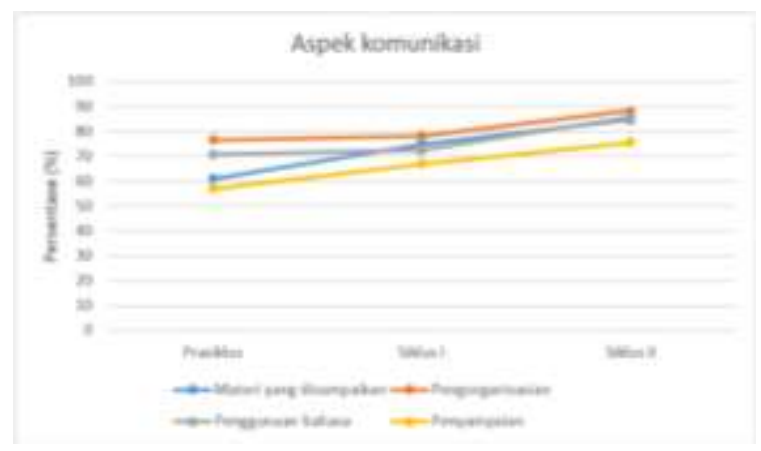

Gambar 3 Peningkatan indikator aspek komunikasi

Gambar 3 menunjukkan perbandingan hasil capaian aspek komunikasi pada setiap siklus. Berdasarkan hasil capaian tersebut diketahui bahwa setiap indikator aspek komunikasi mengalami peningkatan pada setiap siklus.

Kemampuan komunikasi yang baik meningkatkan iklim positif dalam pembelajaran karena menyebabkan transfer pengetahuan antar siswa berjalan dengan baik.

Dalam pembelajaran Investigasi Kelompok kemampuan komunikasi merupakan salah satu komponen yang 
dikembangkan. Kontak, percakapan, saling membantu dan saling mendukung diantara para siswa dalam kelompoknya merupakan bagian dari model investigasi kelompok (Sharan, 2012).

\section{Menghargai}

Dalam setiap kegiatan pembelajaran keterampilan menghargai wajib dimiliki oleh setiap siswa. Sikap menghargai penting dikembangkan dalam pembelajaran karena melalui sikap menghargai akan terbentuk atmosfir pembelajaran yang positif sehingga proses belajar mengajar menjadi semakin nyaman dan menyenangkan. Penerapan investigasi kelompok dalam pembelajaran dapat meningkatkan rasa menghargai siswa terhadap pendapat siswa lain (Hobri \& Susanto, 2006).

Persentase capaian indikator aspek menghargai pada tiap siklus disajikan pada Tabel 3.

Tabel 3. Hasil Capaian Indikator Aspek Menghargai

\begin{tabular}{|c|c|c|}
\hline \multirow{2}{*}{ Indikator } & \multicolumn{2}{|c|}{ Pencapaian (\%) } \\
\hline & Siklus I & Siklus II \\
\hline $\begin{array}{l}\text { Kontribusi } \quad \text { Positif } \\
\text { dalam pembelajaran }\end{array}$ & 66,39 & 72,92 \\
\hline $\begin{array}{l}\text { Mengikuti aturan } \\
\text { pembelajaran }\end{array}$ & 74,17 & 86,61 \\
\hline $\begin{array}{l}\text { Etika dalam mengemu- } \\
\text { kakan pendapat }\end{array}$ & 70,00 & 76,79 \\
\hline
\end{tabular}

Tabel 3 menunjukkan hasil capaian indikator pada aspek menghargai. Berdasarkan tabel tersebut diketahui bahwa capaian tertinggi pada siklus 2 adalah pada indikator mengikuti aturan pembelajaran yaitu 86,61 \% sedangkan kontribusi positif dalam pembelajaran menunjukkan hasil capaian terendah yaitu $72,92 \%$.

Peningkatan hasil capaian setiap indikator pada aspek menghargai disajikan pada Gambar 4.

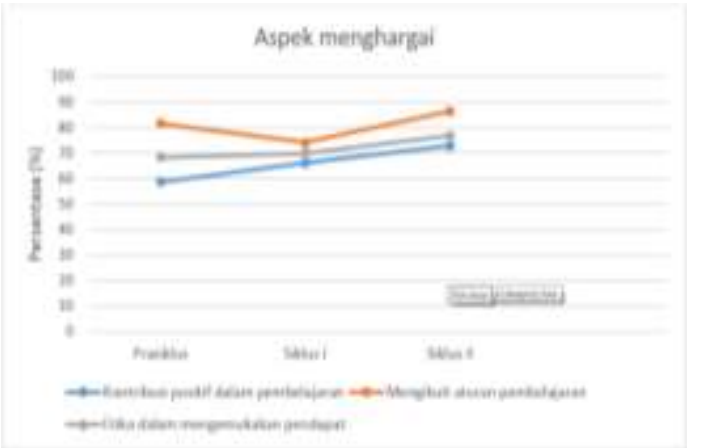

Gambar 4. Peningkatan indikator aspek menghargai

Gambar 4 menunjukkan hasil capaian aspek menghargai pada angket keterampilan sosial siswa. Berdasarkan gambar didapatkan informasi bahwa indikator kontribusi positif dalam pembelajaran dan etika dalam mengemukakan pendapat mengalami peningkatan pada setiap siklus sedangkan indikator mengikuti aturan pembelajaran mengalami penurunan pada siklus 1 namun meningkat pada siklus 2 .

\section{Kesimpulan}

Berdasarkan hasil penelitian ini dapat disimpulkan bahwa penerapan pendekatan kontekstual melalui model pembelajaran investigasi kelompok dapat 
meningkatkan keterampilan sosial siswa kelas X-3 SMA Negeri 1 Boyolali Tahun Pelajaran 2012/2013 yang meliputi 3 aspek yaitu kerjasama, komunikasi dan menghargai.

\section{Daftar Pustaka}

Arends, R.I. 2008. Learning to Teach Belajar untuk Mengajar. Yogyakarta: Pustaka Pelajar

Arikunto, S. 1999. Dasar-dasar Evaluasi Pendidikan. Jakarta: Bumi Aksara

Dahar, R.W. 2010. Teori-teori Belajar dan Pembelajaran. Jakarta: Erlangga

Gulo, W. 2002. Strategi Belajar Mengajar. Jakarta: Grasindo

Hargie, O., Saunders, Christine and Dickson, D. 1998. Social Skill in Interpersonal Communication. London: Routledge

Herimaturida. 2010. Pengaruh Penggunaan Metode Investigasi Kelompok Terhadap Keterampilan Sosial Siswa. Vox Edukasi 1(1) 1 Maret 2010

Hobri dan Susanto. 2006. Penerapan Pendekatan Cooperative Learning Model Group Investigation untuk Meningkatkan Pemahaman Siswa Kelas III SLTPN 8 Jember Tentang Volume. Jurnal Pendidikan Dasar, Vol.7(2), 2006: 74-83

Isjoni. 2012. Pembelajaran Kooperatif: Meningkatkan Kecerdasan Komunikasi Antar Peserta Didik. Yogyakarta: Pustaka Pelajar

Joyce, B., Weil, Marsha, and Calhoun, E. 2009. Models of Teaching: Modelmodel Pembelajaran.Yogyakarta: Pustaka Pelajar

Judy G. 2012. Enhancing social work education through team-based learning. Journal of Social Work Education, 48, (2)

Jumadi. 2003. Pembelajaran Kontekstual Dan Implementasinya. Makalah disampaikan pada Workshop Sosiali- sasi dan Implementasi Kurikulum 2004 Madrayah Aliyah DIY, Jateng, Kalsel di FMIPA UNY, Yogyakarta, 14 - 15 April

Lexy, J. M. 2005. Metodologi Penelitian Kualitatif. Bandung: Rosda Karya

Merrell, K. W. 2001. Assessment of Children's Social Skills: Recent Developments, Best Practices, and New Directions. EXCEPTIONALITY, 9 (1\&2): 3-18

Merrell, K. W., and Gimpel, G. A. 1998. Social skills of children and adolescents: Conceptualization, assessment, treatment. Mahwah, NJ: Lawrence Erlbaum Associates, Inc

Miles and Huberman. 1992. Data Kualitatif. Jakarta: UI Press

Mukhtar, D. and Hadjam, N. R. 2006. Efektivitas Art Therapy Untuk Meningkatkan Keterampilan Sosial pada Anak yang Mengalami Gangguan Perilaku. PSIKOLOGIA, 2(1): $16-24$

Nagel, P. 2008. Moving Beyond Lecture: Cooperative learning and The Secondary Social Studies Classroom. Education, 128 (3)

Ningrum, E. 2009. Pengembangan Strategi Pembelajaran Geografi Berorientasi Keterampilan Sosial Makalah disajikan pada Seminar Nasional Pertemuan Ilmiah Tahunan Ikatan Geografi Indonesia (IGI) Wilayah Jawa Barat dan Musyawarah Wilayah II, Ikatan Mahasiswa Geografi Indonesia (IMAHAGI), Bandung, 9-11 Mei

Nurhadi 2004. Pembelajaran Kontekstual dan Penerapannya dalam KBK. Malang: UM Press

Permen Diknas RI Nomor 22 Tahun 2006 tentang Standar Isi Sekolah Dasar dan Menengah

Puskur. 2002. Kurikulum dan Hasil Belajar: Rumpun Pelajaran Sains. Jakarta: Balitbang Diknas

Puskur. 2002. Kurikulum dan Hasil Belajar Sains di SD. Jakarta: Balitbang Diknas 
Sanjaya, W. 2006. Strategi Pembelajaran Berorientasi standar Proses Pendidikan. Jakarta: Kencana Prenada Media Group

Sharan, S. 2012. The Handbook of Cooperative Learning. Yogyakarta: Familia

Siregar, E., and Nara, H. 2010. Teori Belajar dan Pembelajaran. Bogor: Ghalia Indonesia

Slavin, R. E. 2007. Cooperative Learning: Teori, Riset, dan Praktik. Bandung: Nusamedia

Slavin, R. E. 2010. Cooperative Learning Teori, Riset dan Praktek. Bandung: Nusa Media

Sudjana, N. 1991. Penilaian Hasil Proses Belajar Mengajar. Bandung: Rosda Karya
Suherman. 2001. Strategi Pembelajaran Matematika. Kontemporer. Bandung: Jurusan Pendidikan Matematika UPI Bandung

Supardi. 2009. Penelitian Tindakan Kelas. Jakarta: Gramedia

Sukmadinata, N. S. 2011. Metode Penelitian Pendidikan. Bandung: PT Remaja Rosdakarya

Ulansari, I. dan Yonata, B. 2012. Keterampilan Sosial Siswa Melalu Pembelajaran Kooperatif Tipe STAD pada Materi Pokok Larutan Penyangga Di SMAN 1 Sumberrejo Bojonegoro. Unesa Journal of Chemical Education, 1(1): 136-144 